WIAS Discussion Paper No.2012-006

\title{
Impact of Leverage on Investment by Major Shareholders: Evidence from Listed Firms in China
}

\author{
November 12, 2012
}

Yuan Yuan

Waseda Institute for Advanced Study, Waseda University, Tokyo, Japan

Kazuyuki Motohashi

Department of Technology Management for Innovation, The University of Tokyo

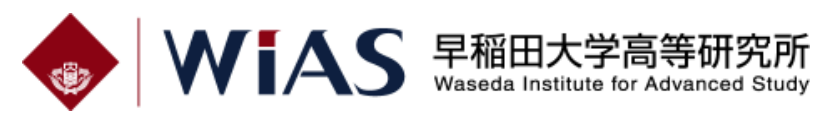

1-6-1 Nishiwaseda, Shinjuku-ku, Tokyo 169-8050, Japan

Tel: +81-3-5286-2460 ; Fax: +81-3-5286-2470 
Impact of Leverage on Investment by Major Shareholders:

Evidence from Listed Firms in China*

\author{
Yuan Yuan*, Associate professor \\ WASEDA Institute for Advanced Study, \\ 1-6-1 Nishiwaseda,Shinjuku-Ku, Tokyo 169-8050, Japan \\ E-mail:yuan@aoni.waseda.jp \\ Kazuyuki Motohashi, Professor \\ Department of Technology Management for Innovation, \\ The University of Tokyo, \\ 7-3-1Hongo Bunkyo-ku, Tokyo 113-8656 Japan, \\ E-mail: motohashi@tmi.t.u-tokyo.ac.jp
}

*Corresponding author. 


\begin{abstract}
In this paper, we analyze whether leverage had impacts on investment in the period 1999-2009, and whether these impacts, if they exist, differed among companies with different investment opportunities and with different major shareholders. In order to identify governance with different major shareholders, we grouped China's listed firms into central government owned firms (CSOEs), local government owned firms (LSOEs) and non-state-owned firms (NONSOEs). Our results are as follows. Firstly, our analysis reveals that leverage does have significantly negative impacts on CSOE, LSOE and NONSOE investments. Secondly, in LSOEs and NONSOEs, negative leverage impacts on low-growth firms are stronger than average firms, implying that a disciplinary effect of leverage over investment can be found in LSOEs and NONSOEs. Finally, however, no such effect can be observed in CSOEs. We have provided a first finding that the effect of leverage varies according to a firm's major shareholders.
\end{abstract}

Keywords: leverage; major shareholders; State ownership; China JEL: G31, G32, G34 


\section{Introduction}

China has become one of the engines of world growth due to its economic size and speed of growth. However, there is some concern about the long-term perspective, since Chinese economic growth depends heavily upon fixed capital formation. The lack of a proper governance mechanism and soft budget problems, particularly found in state-owned enterprises, may cause overinvestment in corporate sectors. In this paper, we investigate the nature of the largest shareholders in China's listed firms, focusing on the impact of leverage on investment.

A large number of previous studies show that if asymmetry of information exists, financing will affect the firms' investment behavior. In other words, in an incomplete market, because there is an agency problem between the debt-holders, managers, and shareholders, this will lead to an overinvestment problem or debt overhang problem (Myers, 1977; Jensen, 1986). Lang et al. (1996), McConnell and Servaes (1995), Ahn et al. (2006), and Aivazian (2005) analyze the debt disciplinary effect by using the financial data of listed firms in the U.S. or Canada.

On the other hand, since many banks in emerging countries are controlled by their governments and tend to be used by politicians, it is generally felt that state-owned banks have little incentive to monitor borrowers. As Sapienza (2004), La Porta et al. (2002) have found, political factors affect the lending behavior of state-owned banks and the banks do not always lend to profitable firms.

Many large banks in China have been listed. However they are still controlled by the government. Up to now, firms almost always borrow from banks and other financial institutions, because the bonds market in China is underdeveloped. It is considered that the lending behavior shown in Sapienza (2004), La Porta et al. (2002), exists in China. Bai et al. (2003) suggest that in order to maintain state-owned firms trading on the market, the government uses bank loans or subsidies to bail out listed firms. Firth et al. (2008) find that as a result of the lending behavior of state-owned banks, bank loans have little effect on the investments of unprofitable firms, particularly for state-owned firms. From these empirical studies, it is considered that the debt disciplinary effect suggested by Jensen (1986), will not function very well for China's firms.

However, as Chen et al. (2009) argue, previous studies have failed to 
identify the nature of the state share, and if the nature of state ownership is ignored, the real impact of the state shareholders will be obscured. They also pointed out that, "In China, the state's ownership of firms is undertaken by different types of agencies and we argue that the objectives of these agency-types dictate the extent of political intervention and the degree of commercialization of listed companies they invest in" (Chen et al. 2009, P172). Therefore, it is considered that the different nature of major state-owned shareholders has different effects on the ease of financing and monitoring of debt-holders in China. It will be very interesting to compare the different leverage effects, not only between state firms and non-state firms, but also between firms with different state shareholders.

In this paper, we provide a thorough empirical analysis of the leverage impacts on listed firms in China by using financial data from 1999 to 2009. Firstly, we look at whether leverages have effects on firms. Secondly, we focus on whether the impacts of leverage on investment are any different among listed firms with differing investment opportunities. Thirdly, we shed light on whether the leverage effects depend on the nature of the largest shareholders. The most important feature of China's listed firms is that the largest shareholders have overwhelming power to control the firms because their ratio is much higher than the second largest shareholders. Thus we group the listed firms in China into three types by the nature of the largest shareholders: CSOEs (firms whose largest shareholders are controlled by the central government), LSOEs (firms whose largest shareholders are the local government or are controlled by the local government), and NONSOEs (firms whose largest shareholders are non-state firms or individuals).

Our method of analysis is described below. First, we add the leverage to an investment equation to examine whether debt sensitivity exists in the investment activities of China's listed firms. Then, similar to Lang et al. (1996), Ahn et al. (2006), Aivazian et al. (2005), and Firth et al. (2008), we use the ratio of the market value to the replacement cost of assets (Tobin's Q), to distinguish corporate growth potential, and add the cross term between them and the leverage to the investment equation. Since high-growth firms have promising investment opportunities, they are believed to be prone to underinvestment due to leverage. On the other hand, as low-growth firms lack promising investment opportunities, their leverages are believed to keep them from overinvestment. 
Firth et al. (2008) studied the impact of bank loans on investment in state-owned enterprises (SOEs) in China, but did not focus on the nature of the SOE shareholders. Unlike Firth et al. (2008), we take a detailed look at the major shareholder, particularly differentiating between CSOEs and LSOEs. CSOEs are typically owned by a large holding company with many subsidiaries. Some of these are flagship companies, listed as one of Fortune 500 companies. On the other hand, LSOEs are generally smaller and do not have the deep pockets of the CSOEs.

Our key findings are as follows. Firstly, we find that the leverage has a significant negative impact on fixed investment. Therefore, managers of LSOEs and NONSOEs care about debt when they make investment decisions, because debt is not free for them. Secondly, we find that leverage works more strongly on low-growth LSOEs and NONSOEs. This means that disciplinary effects of leverage exist in LSOEs and NONSOEs. Thirdly, we find that the disciplinary press of leverage shown in Jensen (1986) does not exist in CSOEs. Therefore, rather than state share or non-state share, we argue that leverage impacts depend on who are the major shareholders.

A number of empirical studies have found the existence of debt disciplinary effects (such as Aivazian et al., 2005; Lang et al., 1996; Ahn et al., 2006), while Firth (2008) has found that bank leverage weakens the debt disciplinary effect on state firms. Our study further investigates the nature of state-owned companies, and in contrast with Firth et al. (2008), we find differences between CSOEs and LSOEs in terms of the debt effect. Our in-depth analysis of the debt disciplinary effect in China by grouping the major shareholders, implies that the nature of major shareholders has an important bearing on whether the overinvestment restraining effect occurs or not. Therefore we contribute not only to studies on the relation between leverage and investment, but also to studies on ownership and debt discipline.

This paper is structured as follows. We survey previous studies on debt and corporate investment in Section 2 and briefly introduce the ownership and motivation of listed firms in China in Section 3. In Section 4, we explain our method of empirical analysis. In Section 5, we introduce our data. We attempt an interpretation of the estimation results in Section 6 , followed by conclusions in Section 7. 


\section{Previous Studies on leverage and investment}

The impact of liabilities on investment decisions by companies has drawn keen attention. According to the Modigliani-Miller Theorem, the level of liabilities does not affect corporate investment behaviors in a perfect market. In other words, given simple assumptions, it is noted that leverage has no effect on fund procurement. However, it is noted that liabilities have negative effects on firms' investment behaviors through the following channels. Firstly, as increased liabilities raise bankruptcy risk, corporate managers worry about the possibility of shareholders holding them accountable, and thus tend to curb borrowings and/or reduce investments. Underinvestment problems may arise as a result. Secondly, as larger interest payment burdens resulting from higher debts reduce funds in hand, so debt has a negative impact on the investment activities of companies with promising investment opportunities. This is called the "debt overhang hypothesis" (Myers, 1977; Stulz, 1990).

Meanwhile, in contrast to the negative effect of liabilities on corporate management, Jensen (1986) points out that liabilities can help avoid overinvestment by reducing the cash flow left up to corporate managers' own discretion and constraining investments in investment projects that might be desirable for corporate managers but not desirable for firms' future profitability. Jensen argues that whether liabilities restrain overinvestment depends largely on whether companies have growth opportunities. In short, Jensen points out that liabilities have (not only the negative effect of causing underinvestment by high-growth companies but also) the potentially positive effect of restraining overinvestment by low-growth firms. Like Jensen (1986), Stulz (1990) and Hart and Moore (1995) argue that liabilities effectively restrain overinvestment. They reason that increased liabilities, by enlarging repayment obligations, not only curtail free cash flow but also raise the possibility of corporate bankruptcies, thus prompting corporate managers to reduce investments and sell off unprofitable business divisions.

Some empirical studies have investigated the relationship between the investment and debt. McConnell and Servaes (1995) use cross-sectional data to analyze U.S. listed companies in 1976, 1986 and 1988. They indicate that market value was negatively correlated with the debt ratio of companies with high growth opportunities and positively correlated with the debt ratio of companies with few growth opportunities. With the exception of 
McConnell and Servaes (1995), most studies use Tobin's Q to classify whether or not firms have investment opportunities. Lang et al. (1996), based on an analysis of the relationship between the debt ratio and the rate of growth of companies, point out that for companies with fewer investment opportunities (i.e. companies with a low Tobin's Q), there is a negative correlation between debt ratio and investment. On the other hand, for firms with excellent investment opportunities, increased liabilities do not necessarily hamper investment. Lang et al. interpret this analytical outcome as reflecting the disciplinary role of liabilities.

Looking at more recent studies, Aivazian et al. (2005) analyze the impact of liabilities on fixed investment using Canadian firm-level data, and demonstrate that companies with fewer investment opportunities are more vulnerable to the impact of liabilities than companies with many investment opportunities. Further, according to Ahn et al. (2006), diversified companies tend to have higher debt ratios than focused counterparts and diversified companies make larger investments (net cost of capital/sales) than focused counterparts. They also point out that debt ratios influence management decisions on investment and that diversified companies can overcome the constraints of debt ratios through the distribution of liabilities service by corporate managers.

Thus, previous studies have verified the impact of leverage on investment in industrial countries as well as the effects of leverage in restraining overinvestment and facilitating underinvestment. However, there are few studies on corporate leverage in developing countries. Firth et al. (2008) examine the effects of bank leverage on investment in China's listed firms and find that the effect of bank leverage is weaker in firms with higher state share and poor performance. However they do not take into account the heterogeneous nature of state-owned enterprises. Thus, in this paper, we attempt to grasp more clearly the leverage impacts on fixed investment in firms by type of major shareholder.

\section{Ownership and motivation of listed firms in China}

The reform of China's enterprises began in the 1980s. In order to deal separately with property rights and management rights, Stated-owned Assets Management Bureaus (SAMBs) were established in 1988 in the central government and in each local government. Assets management 
companies administered state-owned firms under the SAMBs. Therefore, on paper, it appeared as if government and management activities had been separated. In 1995, as a means to promote privatization, the central government set out the policy of "managing the large SOEs (state-owned firms), letting go of the small SOEs" (Zhua da fang xiao in Chinese). At that time, there were 632 SOEs that belonged to the central government and a number of other non-privatized SOEs that belonged to local governments.

Despite the administration by the SAMBs, the governance of SOEs lacked clarity since various ministries controlled different aspects such as financing, personal affairs, and the salaries of employees. In order to resolve this lack of clarity in governance and improve governance overall, or, in a word, in order to prevent the involvement of ministries, the State-owned Assets Supervision and Administration Commission (SASAC) was established in 2003 in the central government and in local governments to replace the SAMBs. OECD (2009) suggests that SOEs' role in the Chinese economy can be presented by the classification of central and local SOEs. Following OECD (2009), we classify China's SOEs into CSOEs and LSOEs (Figure 1).

By July 2008, the number of holding firms managed by SASAC in the central government had fallen to just 149 , but the number of their subsidiary companies and holding companies was still over 10,000 and they continue to play a very important role in the Chinese economy. For example, the total assets of firms managed by SASAC in central government, have risen to make up over $50 \%$ of state firms' the total assets (OECD, 2009). Therefore the largest shareholders of CSOEs are typically the largest and most important firms in key industries, and they have become symbols of the Chinese economy. From 2000, SOEs actively started to internationalize following the "Going-global strategy" (zou chu qu in Chinese) proposed by the government. The government launched several policies to provide funds for overseas investments by SOEs. One of the most important objects was to obtain large-scale overseas resources and acquire high technology from the large SOEs. For example, resource acquisitions by Sinopec around the world have attracted attention in recent years. From the above, it is obvious that CSOEs are the most important firms in China and that their operations reflect the strategy of the central government. The governments control the firms not only through intervention in management but also by providing 
funds. Thus, CSOEs can obtain subsidies from the central government, but can also receive financing from financial institutions much more easily than NONSOEs or LSOEs (OECD, 2009).

The largest shareholders of LSOEs are local SOEs or local SASACs controlled by local governments. Cheung et al. (2008) suggest that local governments may have fewer resources than the central government to perform a social role, leading them to search for alternative sources of revenue. OECD (2009) suggests that listed SOEs are valuable assets for their owners, especially local governments, because the dividends are important revenue sources for them. Hence, in contrast to the central government, local governments have little incentive to provide relief to LSOEs when they fall into difficulty.

The majority shareholders of the NONSOEs are non-state-owned firms or individuals. The government has little influence over them. As in the case of LSOEs, financing from financial institutions and obtaining boosts from the government are not as easy as they are for CSOEs.

From the above, we can conclude that the debt disciplinary effect may be different for CSOEs, LSOEs and NONSOEs. To take an example, one of the largest IT firms, Datang Mobile, whose majority shareholder is a centrally-owned firm, ran into financial difficulties, posting two consecutive years of negative earnings from 2005. By 2007, it was saddled with debts of almost 700 million yuan, three times its annual sales. In 2007, with government involvement, it was able to receive financing of 1.5 billion yuan from the People's insurance Company of China to reorganize. On the other hand, firms whose majority shareholder is a local government will receive different treatment. Aokema, an electronics maker controlled by a local government, found it easy to find financing when the electronics market was strong. However, when the market weakened in 2006, banks and other creditors accelerated repayments, and Aokema faced serious financing difficulties. Although it was able in the end to overcome the shortage of funds with the aid of the local government, we note that financial institutions and governments have differing degrees of incentives towards CSOEs and LSOEs. As a NONSOE firm, for example, Daobo was sued by the Shenzhen Development Bank because it could not afford to repay its debts.

\section{Empirical Analysis}


As with previous studies (Lang, Ofek and Stulz, 1996; Aivazian et al., 2005; and Ahn et al., 2006), the analysis in this paper uses Tobin's Q as a key explanatory variable of the investment equation, and we conduct an estimation by adding the debt ratio to this. A high Tobin's $Q$ indicates a high market value relative to total assets, suggesting that a firm has ample business opportunities. Thus, with the addition of Tobin's $Q$ to the investment equation, it is possible to verify the impact of the debt ratio on fixed investment while controlling companies' business opportunities. As corporate investments are found to be influenced by the availability of internal funds in Fazzari et al. (1988) and Hoshi et al. (1991), the analysis in this paper adds the free cash flow ratio to the estimate equation as a control variable. Following previous studies, we also use total assets as a control variable to control firm's scale.

Investment $_{i, t}=\beta_{0}+\beta_{1}$ Tobin' $^{\prime} Q_{i, t-1}+\beta_{2}$ Leverage $_{i, t-1}+\beta_{3}$ Cash $_{i, t}+\beta_{4} \ln$ size $_{i, t}$

+ Yeardummy $_{t}+\mu_{i}+\varepsilon_{i, t}$

Investment $_{i, t}$ : Fixed investment ratio (fixed investment/total asset) of firm $i$ at time $t$

Tobin' $s Q_{i, t-1}$ : Tobin's $\mathrm{Q}^{1}$ of firm $i$ at time $t-1$

Leverage $_{i, t-1}$ : Leverage (total liabilities/total assets, bank liabilities/total assets) of firm $i$ at time $t-1$; or average leverage during the previous three years of firm $i$ at time $t-1$

$\operatorname{Cash}_{i, t}$ : Ratio of free cash flow to total assets of firm $i$ at time $t$

$\ln$ Size $_{i, t}:$ Log of total assets of firm i at time $t$

${ }^{1}$ Lindenberg and Ross (1981) calculate Tobin's Q as the market value of a company divided by the replacement value of its assets. However, as data available in this study is limited, it is difficult to calculate the replacement value of assets. Since Perfect and Wiles (1994) use the book value of total assets, rather than the replacement value of total assets, as the denominator of Simple $\mathrm{Q}$, we calculate Tobin's Q in this study according to the definition of Simple Q in Perfect and Wiles (1994). Thus, Tobin's Q in this study is (market value + liabilities)/book value of total assets. 
$\mu_{i}:$ Individual effect

$\varepsilon_{i, t}:$ Error term

We add the yeardummy to the estimate equation to take macro factors into consideration. Differing from Firth et al. (2008), we use alternative measures of leverage to examine the relation between leverage and investment. More specifically, one is the total leverage without any regard to the source of funds and the other is the bank leverage (borrowings from banks). Aivazian et al. (2005) point out that an endogeneity problem will occur and estimators will be biased if unobservable factors are ignored. An example given in Firth et al. (2008) is that firms may obtain a bank loan and acquire valuable projects much more easily if they have a good relationship with the government. In this paper, following Aivazian et al. (2005), and Firth et al. (2008), we use not only a fixed effect model, but also instrument variables in order to avoid the endogeneity problem and biased estimation results. We also use the average leverage during the previous three years to check the robustness.

In previous studies, debt was found to exert a differing influence on investment by companies with high or low values of $\mathrm{Q}$, apparently because the value of $\mathrm{Q}$ represents the extent of ease of access to funds on the capital market. In other words, since companies with greater investment opportunities (a high Tobin's Q) find it relatively easy to finance on the capital market, their investments are less sensitive to the level of debt. On the other hand, since companies with few investment opportunities find it relatively difficult to raise funds on the market, they appear to be more sensitive to the level of debt in their investment decisions. Lang et al. (1996), Aivazian et al. (2005) and Arikawa et al. (2003) differentiate the investment opportunities of firms using the value of Tobin's $Q$ and demonstrate that firms with few investment opportunities respond more strongly to the level of debt than firms with greater investment opportunities. In this paper we also define low-growth firms with the use of Tobin's Q, and examine differences in the impact of the level of debt on investment by average firms and low-growth firms. Here, lower one-third of companies in terms of the value of Tobin's $Q$ are defined as low-growth firms (LQ). Therefore, on the basis of equation (1), we also estimate the following equation (2), with the addition of the cross terms of the leverage with the low growth firm dummy. 
Investment $_{i, t}=\beta_{0}+\beta_{1}$ Tobin' $Q_{i, t-1}+\beta_{2}$ Leverage $_{i, t}+\beta_{3} L Q_{i, t-1} \times$ Leverage $_{i, t-1}+\beta_{4}$ Cash $_{i, t}$ $+\beta_{5} \ln$ size $_{i, t}+$ yeardummy $+\mu_{t}+\varepsilon_{i, t}$

\section{Data}

This study makes use of the China Stock Market Financial Database Annual Report and China Listed Firm's Corporate Governance Research Database, both provided by GTA Information Technology Co., Ltd. We used the 1999-2009 financial data for manufacturing companies listed on the Shanghai and Shenzhen stock exchanges. We choose 1999 as the starting year because shareholder information was only available from that year. Furthermore, even if we were to acquire shareholder information for the years prior to 1999, this would not be appropriate since new accounting principles (GAAP)2 have been implemented by listed firms from 1998. The database includes financial data for 1693 listed firms at the end of 2009 . However, due to missing data and outliers (three standard deviations from the mean), the data for fewer than 1,693 firms was actually used. Our data is an unbalanced panel containing 7,128 samples.

In China, the types of shareholders are categorized into state, local legal person, foreign legal person, management, employee, and individual. China Listed Firm's Corporate Governance Research Database contains information about the largest shareholders, such as the name of the largest shareholder and type of the largest shareholder. This database has no information about CSOEs or LSOEs. However the names of holding companies controlled by the SASAC in the central government are listed on the website of the SASAC $^{3}$. We use this list to divide firms whose largest shareholder is the state into CSOEs and LSOEs, while those whose largest shareholders are not the state, such as local legal persons, are defined as NONSOEs.

China's financial markets, including the stock and bond markets, are not as fully developed as those of other developed countries. The Shanghai Stock Exchange was established in 1990 and the Shenzhen Stock Exchange in

2 "Gu Fen You Xian Gong Si Kuai Ji Zhi Du" in Chinese.

3 The address of the SASAC website is as follows.

http://www.sasac.gov.cn/n1180/n1226/n2425/index.html 
1991. Yet, the most important financing methods for listed companies, other than their own funds in hand, remains trade credit and borrowings from banks. Until now, the most important debt-holder for listed firms in China are financial institutions.

Table 1 shows changes in the two measures of leverage by CSOEs, LSOEs, and NONSOEs during the period 1999-2009. The median total leverage for all samples increased to $50 \%$ from 2005. The median bank leverage for all samples hovered between 19\% and 24\% from 1999 to 2009 . The trends in total leverages are very similar among the three types of firms, which are on upward trend. However, different trends of bank leverage are showed among three types of firms. CSOEs present increasing trend, while LSOEs and NONSOEs show decreasing trend from 2006 and 2003 respectively.

Table 2 lists the definitions of the variables used in the models in the preceding section, while Table 3 shows the descriptive statistics of these variables. The mean of the investment ratio (fixed investment/total assets) is 0.1 for all firms. The mean of NONSOEs is a little higher than that of LSOEs, and NONSOEs also have a larger standard deviation. The leverages of CSOEs are not higher ratio than LSOEs and NONSOEs, while CSOEs have a lower Tobin's Q than LSOEs and NONSOEs. The average value of Tobin's $\mathrm{Q}$ is 2.22 for all samples. The factors behind the high value of Tobin's $\mathrm{Q}$ for listed firms in China apparently include the market's high expectations for growth opportunities of Chinese firms due to the high growth of the Chinese economy in recent years. ${ }^{4}$

Table 4 shows the correlations between the variables used in the analysis in this paper. The two alternative measures of leverage, are negatively correlated with investment. From Table 4, we consider that multicollinearity is not a serious problem because of low correlation among explanatory variables.

\section{Estimation Results}

\subsection{Basic Estimation Result}

Table 5 shows the basic estimation results of equation (1) by using the two alternative measures of leverage for the three types of firms. We use the

${ }^{4}$ Chen et al. (2009), Huang and Song (2006), Lin and Su (2008) also calculate Tobin's Q for listed companies and come up with a high value of over 2 . 
method shown in White (1980) to obtain a robust standard error. Columns 1-4 show the estimation results of the impact of the total leverage on fixed investment. The impact of the total leverage on investment is significantly negative at the $1 \%$ level. The sensitivity of fixed investment to the total leverage is around -0.166 for CSOEs, -0.064 for LSOEs, and -0.066 for NONSOEs. This indicates that the total leverage does have a negative impact on investment by Chinese listed firms. In addition, as Tobin's Q, an indication of available investment opportunities, is significantly positive at the $1 \%$ level, except for CSOEs, the estimation results show that firms with a higher value of $\mathrm{Q}$ invest more. Since free cash flow ratio and total assets, the control variables, have a significantly positive correlation to investment, it is implied that firms with ample internal funds or large-scale firms tend to make large amounts of investments.

Columns 5-8 show the impact on investment by bank leverage. Columns 5-8 show that the impact of bank leverage on investment is significantly negative at at least the $10 \%$ level. Tobin's $\mathrm{Q}$, which controls investment opportunities for firms, is significantly positive at the $1 \%$ level, except for CSOEs. The estimation results of free cash flow ratio, and total assets are consistent with columns $1-4$. The estimation results in this section confirm that leverage has negative impacts on investment. We can conclude that leverage is not a free source for CSOEs, LSOEs and NONSOEs. However, Table 5 does not differentiate between underinvestment due to high leverage and restraint of overinvestment due to the disciplinary effect of the leverage.

To examine differences in the impact of leverage on investment by average firms and low-growth firms, we estimate equation (2), which adds the debt ratios and the respective cross terms of the dummy for low-growth firms (LQ) and the leverages. Table 6 shows the estimation results. The subject of greatest interest in this paper is to investigate the leverage effect on investment for different shareholders. Columns 1-4 show the impact of the total leverage on fixed investment. It is confirmed anew that the total leverage has significantly negative impacts at the $1 \%$ level. It is also reaffirmed that Tobin's $\mathrm{Q}$ is significantly positive for investment except for CSOEs. The cross term of the dummy for low-growth firms and total leverage is significantly negative at the 1\% level, except for CSOEs. In other words, we find that the sensitivity of low-growth LSOEs to the total leverage $(-0.058-0.041)$ is higher than that of average LSOEs $(-0.058)$ and the 
sensitivity of low growth NONSOEs $(-0.064-0.049)$ is higher than that of average NONSOEs $(-0.064) .5$ The estimation results suggest that low-growth LSOEs or NONSOEs, which do not have highly profitable investment opportunities, tend to respond more strongly to the disciplinary effect of total leverage. Generally speaking, low-growth companies show a tendency toward overinvestment. Thus, total leverage appears to restrain overinvestment by curbing investment by low-growth firms, which have a tendency toward overinvestment. This therefore implies that the disciplinary effect of restrained overinvestment occurs in LSOEs and NONSOEs. These estimation results are consistent with the results from U.S. firms by Lang, Ofek and Stulz (1996) as well as the estimation results concerning Japanese companies of Arikawa et al. (2003). However, we failed to find the disciplinary effect of total liabilities in CSOEs. For control variables, it is shown again that free cash flow and total assets have significantly positive impacts on investment.

Columns 5-8 show the results of the analysis on the differences in the impact of bank leverage on investment by high-growth and low-growth firms. Again it is confirmed that bank leverage has a significantly negative impact on investment at the $10 \%$ level. The impact of Tobin's $\mathrm{Q}$ on investment is significantly positive for LSOEs and NONSOEs. The cross term for LQ and bank leverage is significantly negative at the $1 \%$ level, except for CSOEs. In other words, the sensitivity of low-growth LSOEs and NONSOEs is higher than that of average firms. These estimation results indicate that the disciplinary effect of bank leverage restrains overinvestment by LSOEs and NONSOEs. However, we do not find any evidence that Chinese banks restrain overinvestment by CSOEs through their lending operations.

Again, the results of average leverage over the previous three years in Tables 7 and 8 confirm our previous findings that there is a negative leverage effect on investment and that the negative leverage effect is large for the low-growth LSOEs and NONSOEs but not for the low-growth CSOEs.

Although the leverage used in our analysis is based on figures for the prior accounting year, it is thought that China's firms set the level of investment in the current year on the basis of the composition of capital at the prior years. Thus, using the investment equation, we find that leverage restrains overinvestment by LSOEs and NONSOEs, but do not find any

${ }^{5}$ Here, the absolute value of the coefficient is defined as the sensitivity. 
evidence of this for CSOEs. Since CSOEs are the most important firms in the key industries, they tend to be used as a channel for attaining political goals, or soft budget constraints, and thus debt-holders impose few restrictions on investments by low growth CSOEs.

\subsection{Estimation of instrumental variables (IV)}

In the baseline regression, we employed Tobin's $\mathrm{Q}$ to control investment opportunities. However, as Aivazian et al. (2005) suggest that investment opportunities are affected by not only public information (Tobin's Q) but also inside information, some omitted variables may therefore lead to an estimation bias. Further, as Firth et al. (2008) suggest, a negative relation between investment and leverage may occur due to a manager's perception of gloomy prospects. In this section, we use the instrument variable method to improve this endogeneity problem.

Aivazian et al. (2005) indicate that tangible assets increase the use of the leverage by reducing the bankruptcy cost, and find that the correlation between tangible assets and investment opportunities is not high. At the first stage, the firm's leverage decision function consists of the ratio of tangible assets to total assets, as instrumental variables, and those in the investment function as control variables. We conduct an F-test to test the hypothesis that the instruments cannot explain firm leverage, and we reject this hypothesis at the $1 \%$ level. Though the results of the first stage are not shown here in the interest of terseness, we can provide the first stage regression results upon request.

Table 9 reports the estimation results of the instrument variable method for equation (1) for different leverages and different types of firms. It shows that the negative relationship between investment and leverage is statistically significantly at the $1 \%$ level for LSOEs and NONSOEs. Table 10 shows the estimation results for equation (2). The interactive term of firms with low growth opportunities and leverage are statistically significantly negative for LSOEs and NONSOEs. This means that the effects of leverage on investment by low-growth firms are larger than the average of firms. We fail to find a larger negative effect of leverage on investment by low-growth CSOE's.

As with Firth et al (2008), the coefficients of the instrument variable method are larger than OLS coefficients. Firth et al (2008, pp.650) explained 
that "the existence of potential measurement error, which would tend to 'attenuate' the coefficient estimate toward zero" is a "regular finding in the finance and growth literature." Overall, we obtained consistent results for the relation between leverage and investment by using the fixed effect model and the instrument variable method.

\section{Conclusions}

In this paper, we employ a panel financial data set for China's listed firms in order to analyze whether leverage had impacts on investment in the period 1999-2009, and whether these impacts, if they exist, differ among companies with different investment opportunities and with different major shareholders. In order to identify governance with different major shareholders, we grouped China's listed firms into CSOEs, LSOEs and NONSOEs. Our results are as follows. Firstly, our analysis reveals that leverage does have significantly negative impacts on investments by CSOEs, LSOEs and NONSOEs. Secondly, in LSOEs and NONSOEs, negative leverage impacts on low-growth firms are stronger than for average firms, implying that a disciplinary effect of leverage over investment can be found in LSOEs and NONSOEs. Finally, however, no such disciplinary effect can be observed in CSOEs.

In contrast to Firth et al. (2008), who suggest that banks impose fewer restrictions on the capital expenditures of state-owned firms, grouping the firms into three types according to the largest shareholders, we find that the debt disciplinary effect over investment can be found not only in non-state-owned firms but also in local government owned firms. This paper suggests that the corporate governance mechanism in state-owned enterprises in China is not always inefficient. Through it, we contribute to the literature on transitional economies by distinguishing the monitoring functions of different types of state shareholders under China's gradual privatization process. Our findings can contribute toward a better understanding not only of the differences in investment behaviors of listed firms with different ownership identities, but also the nature and characteristics of economic reforms in China.

\section{Acknowledgements}


The authors would like to express their gratitude also to Yasuhiro Arikawa, Takuma Matsuda, Hideaki Miyajima, Katsuyuki Kubo, Shinichi Hirota and Qingyuan Sui for their valuable comments.

\section{References}

Ahn, S., Denis, D.J., Denis, D.K., 2006. Leverage and investment in diversified firms. Journal of Financial Economics 79, 317-337.

Aivazian, V.A., Ge, Y., Qiu, J.P., 2005. The impact of leverage on firm investment: Canadian evidence. Journal of Corporate Finance 11, 277-291.

Arikawa, Y., Miyajima, H., Saito, N., 2003, "Kinyūkiki zengo no tōshi kōdō to kigyō tōchi - kajō saimu mondai to main bank" in: Hanazaki, M., Teranishi, J. (eds.), Corporate governance no keizai bunseki - henkakuki no nihon to kinyūkikigo no higashi Asia, University of Tokyo Press, (in Japanese).

Bai, C., Qia, L., Song, F., 2003. Value of corporate control: evidence from China's distressed firms. Unpublished mimeo.

Chen G., Firth, M., Xu, L., 2009. Does the type of ownership control matter? Evidence from China's listed companies. Journal of Banking \& Finance 33, 171-181.

Cheung, Y.L., Rau, P.R., Stouraitis, A., 2008. The helping hand, the lazy hand, or the grabbing hand? Central vs. local government shareholders in publicly listed firms in China. Working Paper Series of Institute of Economic Research, Hitotsubashi University.

Diamond, D.W., 1989. Reputation acquisition in debt markets. Journal of Political Economy 97, 828-862.

Fazzari, S.M., Hubbard, R.C., Petersen, B.C., 1988. Financing constraints and corporate investment. Brookings Papers on Economic Activity 1, 141-195.

Firth, M., Lin, C., Wong, S.M.L., 2008. Leverage and Investment under a state-owned bank lending environment: Evidence from China. Journal of Corporate Finance 14, 642-653.

Grullon, G., Kanatas, G., Kumer, P., 2006. The impact of capital structure on advertising competition: an empirical study. Journal of Business 79, 3101-3124.

Hart, O., Moore, J., 1995. Debt and seniority: An analysis of the role of hard claims in constraining management. American Economic Review 85, 567-858.

Hoshi, T., Kasyap, A., Scharffsein, D., 1991. Corporate structure, liquidity, and investment: Evidence from Japanese industrial groups. Quarterly Journal of Economics 106, 33-60.

Huang, G., Song, F.M. 2006. The determinants of capital structure: Evidence from China. China Economic Review 17, 14-36.

Jensen, M. C., 1986. Agency costs of free cash flow, corporate finance, and takeover. 
American Economic Review 76, 323-329.

Lang, L., Ofek, E., Stulz, R. M., 1996. Leverage, investment, and firm growth. Journal of Financial Economics 40, 3-29.

La porta, R., Lopez de silanes, F., Shleifer, A., 2002. Government ownership of banks. Journal of Finance 57,265-601.

Lin, C., Su, D., 2008. Industrial diversification, partial privatization and firm valuation: Evidence from publicly listed firms in China. Journal of Corporate Finance 14, 405-417.

Lindenberg, E.B., Ross, S.A., 1981. Tobin's q ratio and industrial organization. Journal of Business 54, 1-32.

McConnell, J.J., Servaes, H., 1995. Equity ownership and the two faces of debt. Journal of Financial Economics 39, 131-157.

Myers, S.C., 1977. Determinants of corporate borrowing. Journal of Financial Economics 5, $147-175$.

OECD, 2009. State owned enterprises in China: Reviewing the evidence. www.oecd.org/dataoecd/14/30/42095493.pdf

Perfect, S.B., Whiles, K.W., 1994. Alternative constructions of Tobin's q: An empirical comparisons. Journal of Empirical Finance 1, 313-341.

Sapienza, P., 2004. The effects of government ownership on bank lending. Journal of Financial Economics 72,357-384

Stulz, R.M., 1990. Managerial discretion and optimal financing policies. Journal of Financial. Economics 26, 3-27.

White, H., 1980. A Heteroskedasticity-Consistent covariance matrix estimator and a direct test for heteroskedasticity. Economica 48, 817-838. 


\section{Figure1 Classification of state owned firms}

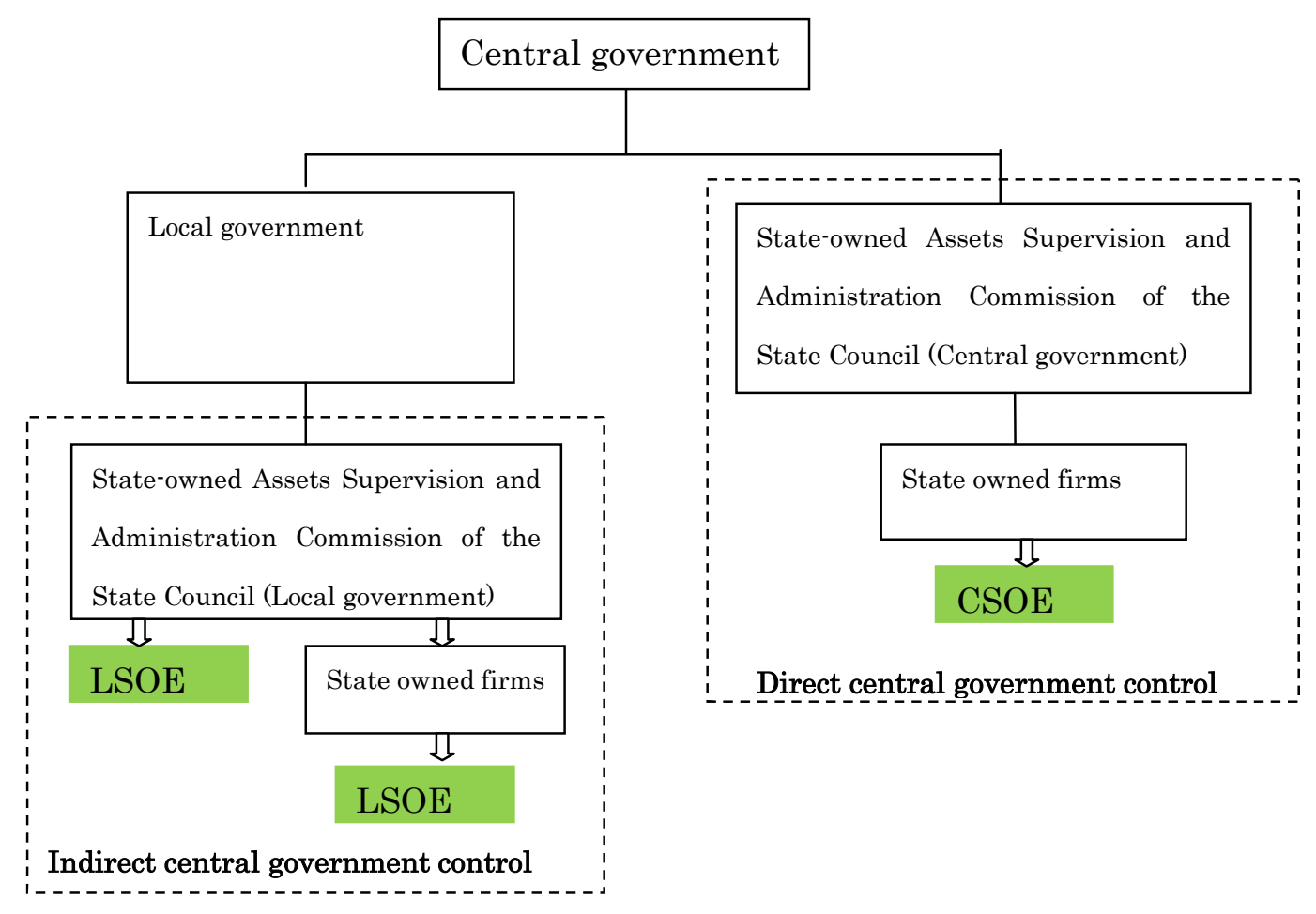


Table1 Trends of leverages

\begin{tabular}{|c|c|c|c|c|c|c|}
\hline \multicolumn{7}{|c|}{ All Samples } \\
\hline & \multicolumn{3}{|c|}{ Total liabilities/Total assets } & \multicolumn{3}{|c|}{ Bank loan/Total assets } \\
\hline Year & Mean & Median & St.dev. & Mean & Median & St.dev. \\
\hline 1999 & 0.420 & 0.407 & 0.182 & 0.208 & 0.194 & 0.137 \\
\hline 2000 & 0.427 & 0.412 & 0.193 & 0.206 & 0.192 & 0.141 \\
\hline 2001 & 0.477 & 0.425 & 0.599 & 0.235 & 0.213 & 0.233 \\
\hline 2002 & 0.509 & 0.447 & 0.615 & 0.243 & 0.221 & 0.252 \\
\hline 2003 & 0.548 & 0.468 & 1.030 & 0.261 & 0.236 & 0.373 \\
\hline 2004 & 0.550 & 0.498 & 0.723 & 0.261 & 0.242 & 0.298 \\
\hline 2005 & 0.638 & 0.522 & 1.682 & 0.277 & 0.239 & 0.533 \\
\hline 2006 & 0.654 & 0.538 & 2.010 & 0.271 & 0.231 & 0.622 \\
\hline 2007 & 0.601 & 0.510 & 2.057 & 0.252 & 0.222 & 0.592 \\
\hline 2008 & 0.624 & 0.512 & 3.123 & 0.254 & 0.213 & 0.839 \\
\hline 2009 & 0.562 & 0.503 & 1.349 & 0.225 & 0.195 & 0.373 \\
\hline \multicolumn{7}{|c|}{ CSOE Samples } \\
\hline & \multicolumn{3}{|c|}{ Total liabilities/Total assets } & \multicolumn{3}{|c|}{ Bank loan/Total assets } \\
\hline Year & Mean & Median & St.dev. & Mean & Median & St.dev. \\
\hline 1999 & 0.401 & 0.403 & 0.173 & 0.181 & 0.196 & 0.130 \\
\hline 2000 & 0.387 & 0.347 & 0.175 & 0.156 & 0.145 & 0.131 \\
\hline 2001 & 0.407 & 0.422 & 0.166 & 0.169 & 0.177 & 0.131 \\
\hline 2002 & 0.440 & 0.440 & 0.163 & 0.176 & 0.171 & 0.144 \\
\hline 2003 & 0.436 & 0.404 & 0.169 & 0.187 & 0.169 & 0.141 \\
\hline 2004 & 0.458 & 0.448 & 0.164 & 0.217 & 0.217 & 0.153 \\
\hline 2005 & 0.500 & 0.510 & 0.158 & 0.229 & 0.220 & 0.169 \\
\hline 2006 & 0.548 & 0.542 & 0.253 & 0.253 & 0.239 & 0.183 \\
\hline 2007 & 0.540 & 0.524 & 0.242 & 0.253 & 0.228 & 0.178 \\
\hline 2008 & 0.542 & 0.556 & 0.190 & 0.262 & 0.223 & 0.201 \\
\hline 2009 & 0.549 & 0.571 & 0.209 & 0.263 & 0.247 & 0.203 \\
\hline \multicolumn{7}{|c|}{ LSOE Samples } \\
\hline & \multicolumn{3}{|c|}{ Total liabilities/Total assets } & \multicolumn{3}{|c|}{ Bank loan/Total assets } \\
\hline Year & Mean & Median & St.dev. & Mean & Median & St.dev. \\
\hline 1999 & 0.432 & 0.425 & 0.184 & 0.217 & 0.207 & 0.136 \\
\hline 2000 & 0.436 & 0.417 & 0.198 & 0.213 & 0.199 & 0.139 \\
\hline 2001 & 0.482 & 0.426 & 0.659 & 0.239 & 0.213 & 0.242 \\
\hline 2002 & 0.494 & 0.446 & 0.501 & 0.240 & 0.225 & 0.210 \\
\hline 2003 & 0.488 & 0.463 & 0.325 & 0.240 & 0.236 & 0.162 \\
\hline 2004 & 0.511 & 0.499 & 0.354 & 0.251 & 0.242 & 0.170 \\
\hline 2005 & 0.623 & 0.518 & 2.018 & 0.277 & 0.269 & 0.633 \\
\hline 2006 & 0.671 & 0.543 & 2.584 & 0.284 & 0.238 & 0.812 \\
\hline 2007 & 0.659 & 0.530 & 2.857 & 0.269 & 0.227 & 0.813 \\
\hline 2008 & 0.536 & 0.548 & 0.217 & 0.236 & 0.224 & 0.161 \\
\hline 2009 & 0.541 & 0.554 & 0.246 & 0.228 & 0.207 & 0.173 \\
\hline \multicolumn{7}{|c|}{ NONSOE Samples } \\
\hline & \multicolumn{3}{|c|}{ Total liabilities/Total assets } & \multicolumn{3}{|c|}{ Bank loan/Total assets } \\
\hline Year & Mean & Median & St.dev. & Mean & Median & St.dev. \\
\hline 1999 & 0.394 & 0.373 & 0.178 & 0.193 & 0.175 & 0.143 \\
\hline 2000 & 0.411 & 0.387 & 0.182 & 0.196 & 0.188 & 0.147 \\
\hline 2001 & 0.481 & 0.419 & 0.467 & 0.244 & 0.223 & 0.225 \\
\hline 2002 & 0.584 & 0.450 & 0.956 & 0.271 & 0.216 & 0.376 \\
\hline 2003 & 0.722 & 0.485 & 0.190 & 0.330 & 0.253 & 0.663 \\
\hline 2004 & 0.643 & 0.502 & 1.162 & 0.290 & 0.242 & 0.461 \\
\hline 2005 & 0.694 & 0.528 & 0.122 & 0.288 & 0.243 & 0.395 \\
\hline 2006 & 0.654 & 0.528 & 1.071 & 0.256 & 0.224 & 0.267 \\
\hline 2007 & 0.543 & 0.492 & 0.592 & 0.231 & 0.214 & 0.205 \\
\hline 2008 & 0.732 & 0.461 & 4.668 & 0.272 & 0.205 & 1.243 \\
\hline 2009 & 0.572 & 0.478 & 1.680 & 0.219 & 0.181 & 0.446 \\
\hline
\end{tabular}


Table 2 Definition of variables

\begin{tabular}{|c|c|c|}
\hline \multicolumn{2}{|r|}{ Variables } & \multirow{2}{*}{$\begin{array}{c}\text { Definitions } \\
\text { Cash paid to acquire fixed assets, etc./total assets }\end{array}$} \\
\hline Investment $_{i, t}$ & Fixed investment ratio for firm $i$ at time $t-1$ & \\
\hline \multirow{2}{*}{ Debt $t_{i, t-1}$} & Total liabilities ratio for firm $i$ at time $\mathrm{t}-1$ & Total liabilities/total assets \\
\hline & Bank liabilities ratio for firm $i$ at time $t-1$ & Bank liabilities/total assets \\
\hline $\operatorname{Cash}_{i, t}$ & Cash flow for firm $i$ at time $\mathrm{t}-1$ & $($ Net profit + depreciation of fixed assets)/fixed assets $t-1$ \\
\hline$Q_{i, t-1}$ & Tobin's $Q$ for firm i at time $\mathrm{t}-1$ & (Number of shares $\mathrm{x}$ average stock price + total liabilities $) /$ total assets \\
\hline$L Q_{i, t-1}$ & $\begin{array}{l}\text { Dummy for Tobin's } Q \text { for firm } \mathrm{i} \text { at time } \mathrm{t}-1 \text { being in the lower } \\
\text { one-third }\end{array}$ & Dummy for low-growth firms \\
\hline size $_{i, t}$ & Firm size & natural logarithm of total assets \\
\hline Yeardummy & Yeardummy & \\
\hline
\end{tabular}


WIAS Discussion Paper No.2012-006

Table 3 Descriptive statistics

\begin{tabular}{|c|c|c|c|c|c|c|c|c|c|c|c|c|}
\hline \multirow[b]{2}{*}{ Variable } & \multicolumn{3}{|c|}{ All } & \multicolumn{3}{|c|}{ CSOES } & \multicolumn{3}{|c|}{ LSOEs } & \multicolumn{3}{|c|}{ NONSOEs } \\
\hline & Obs & Mean & Std. Dev. & Obs & Mean & Std. Dev. & Obs & Mean & Std. Dev. & Obs & Mean & Std. Dev. \\
\hline Investment & 7361 & 0.10 & 0.09 & 606 & 0.10 & 0.08 & 4148 & 0.10 & 0.09 & 2607 & 0.10 & 0.10 \\
\hline Bank leverage & 7418 & 0.23 & 0.16 & 609 & 0.22 & 0.17 & 4192 & 0.23 & 0.15 & 2617 & 0.24 & 0.19 \\
\hline Total leverage & 7477 & 0.50 & 0.30 & 614 & 0.49 & 0.21 & 4213 & 0.48 & 0.23 & 2650 & 0.52 & 0.39 \\
\hline Tobin's Q & 7423 & 2.22 & 1.35 & 614 & 2.14 & 1.32 & 4192 & 2.19 & 1.30 & 2617 & 2.28 & 1.44 \\
\hline Size & 8449 & 15.80 & 0.98 & 647 & 16.14 & 1.10 & 4743 & 15.90 & 0.94 & 3059 & 15.57 & 0.97 \\
\hline
\end{tabular}


Table 4 Correlation of variables

\begin{tabular}{|c|c|c|c|c|c|c|}
\hline & 1 & 2 & 3 & 4 & 5 & 6 \\
\hline 1.Investment & 1 & & & & & \\
\hline 2.Total leverage & -0.19 & 1 & & & & \\
\hline 3.Bank leverage & -0.08 & 0.68 & 1 & & & \\
\hline 4.Tobin's Q & 0.10 & -0.03 & -0.12 & 1 & & \\
\hline 5.Size & 0.18 & 0.03 & 0.08 & -0.38 & 1 & \\
\hline 6.Cash & 0.33 & -0.20 & -0.25 & 0.12 & 0.21 & 1 \\
\hline
\end{tabular}

Note: In this table Total leverage and Bank leverage are the leverages for the prior accounting year. For terseness, the correlation about average leverage over previous three years upon request. 
Table 5 Results for Equation (1) (Fixed effect model ; leverage for the prior accounting year)

\begin{tabular}{|c|c|c|c|c|c|c|c|c|}
\hline & \multicolumn{4}{|c|}{ Leverage $=($ Total Liabilities/Total assets $) \mathrm{t}-1$} & \multicolumn{4}{|c|}{ Leverage $=($ Bank Liabilities/Total assets $) \mathrm{t}-1$} \\
\hline & All & CSOEs & LSOEs & NONSOEs & All & CSOEs & LSOEs & NONSOEs \\
\hline & 1 & 2 & 3 & 4 & 5 & 6 & 7 & 8 \\
\hline \multirow[t]{2}{*}{ Leverage } & $-0.057 * * *$ & $-0.166^{* * *}$ & $-0.064 * * *$ & $-0.066^{* * *}$ & $-0.105 * * *$ & $-0.085^{*}$ & $-0.104 * * *$ & $-0.138 * * *$ \\
\hline & -0.007 & -0.043 & -0.013 & -0.013 & -0.011 & -0.044 & -0.015 & -0.02 \\
\hline \multirow[t]{2}{*}{ Tobin's $Q^{t-1}$} & $0.013^{* * *}$ & 0.005 & $0.015^{* * *}$ & $0.013 * * *$ & $0.012 * * *$ & 0.005 & $0.014 * * *$ & $0.012 * * *$ \\
\hline & -0.001 & -0.003 & -0.002 & -0.002 & -0.001 & -0.003 & -0.002 & -0.002 \\
\hline \multirow[t]{2}{*}{ Size } & $0.026^{* * *}$ & $0.045^{* * *}$ & $0.033 * * *$ & 0.008 & $0.031 * * *$ & $0.038 * * *$ & $0.038^{* * *}$ & $0.014^{* *}$ \\
\hline & -0.003 & -0.009 & -0.004 & -0.006 & -0.003 & -0.009 & -0.004 & -0.006 \\
\hline \multirow[t]{2}{*}{ Cash } & $0.236^{* * *}$ & $0.226^{* * *}$ & $0.226^{* * *}$ & $0.225^{* * *}$ & $0.217 * * *$ & $0.231^{* * *}$ & $0.212^{* * *}$ & $0.188 * * *$ \\
\hline & -0.016 & -0.064 & -0.024 & -0.03 & -0.017 & -0.067 & -0.024 & -0.03 \\
\hline \multirow[t]{2}{*}{ Constant } & $-0.317 * * *$ & $-0.592 * * *$ & $-0.456 * * *$ & -0.019 & $-0.389 * * *$ & $-0.552 * * *$ & $-0.543 * * *$ & -0.118 \\
\hline & -0.048 & -0.144 & -0.07 & -0.104 & -0.048 & -0.142 & -0.07 & -0.102 \\
\hline Yeardummy & Yes & Yes & Yes & Yes & Yes & Yes & Yes & Yes \\
\hline Observations & 7128 & 574 & 4048 & 2506 & 7072 & 569 & 4028 & 2475 \\
\hline Number of Stock Code & 994 & 109 & 628 & 655 & 993 & 108 & 628 & 654 \\
\hline R-squared & 0.15 & 0.18 & 0.15 & 0.15 & 0.15 & 0.16 & 0.15 & 0.15 \\
\hline \multicolumn{9}{|c|}{\begin{tabular}{|l|l|} 
Robust standard errors in parentheses & \\
\end{tabular}} \\
\hline \multicolumn{5}{|c|}{$*$ significant at $10 \% ; * *$ significant at $5 \% ; * * *$ significant at $1 \%$} & & & & \\
\hline
\end{tabular}


Table 6 Results for Equation (2) (Fixed effect model; leverage for the prior accounting year)

\begin{tabular}{|c|c|c|c|c|c|c|c|c|}
\hline & \multicolumn{4}{|c|}{ Leverage $=($ Total Liabilities $/$ Total assets $) \mathrm{t}-1$} & \multicolumn{4}{|c|}{ Leverage $=($ Bank Liabilities $/$ Total assets $) \mathrm{t}-1$} \\
\hline & All & CSOEs & LSOEs & NONSOEs & All & CSOEs & LSOEs & NONSOEs \\
\hline & 1 & 2 & 3 & 4 & 5 & 6 & 7 & 8 \\
\hline \multirow[t]{2}{*}{ Leverage } & $-0.053 * * *$ & $-0.165^{* * *}$ & $-0.058 * * *$ & $-0.064 * * *$ & $-0.086^{* * *}$ & $-0.078^{*}$ & $-0.084 * * *$ & $-0.118^{* * *}$ \\
\hline & -0.007 & -0.044 & -0.012 & -0.012 & -0.011 & -0.046 & -0.015 & -0.02 \\
\hline \multirow[t]{2}{*}{ LQ $\times$ Leverage } & $-0.043 * * *$ & -0.003 & $-0.041^{* * *}$ & $-0.049 * * *$ & $-0.063 * * *$ & -0.017 & $-0.060 * * *$ & $-0.081 * * *$ \\
\hline & -0.005 & -0.016 & -0.007 & -0.009 & -0.009 & -0.031 & -0.012 & -0.017 \\
\hline \multirow[t]{2}{*}{ Tobin's $\mathrm{Q}_{\mathrm{t}-1}$} & $0.013 * * *$ & 0.005 & $0.015^{* * *}$ & $0.013 * * *$ & $0.012 * * *$ & 0.006 & $0.014 * * *$ & $0.012 * * *$ \\
\hline & -0.001 & -0.003 & -0.002 & -0.002 & -0.001 & -0.003 & -0.002 & -0.002 \\
\hline \multirow[t]{2}{*}{ Size } & $0.030 * * *$ & $0.045^{* * *}$ & $0.037 * * *$ & $0.012 *$ & $0.034^{* * *}$ & $0.038 * * *$ & $0.040 * * *$ & $0.018 * * *$ \\
\hline & -0.003 & -0.009 & -0.004 & -0.007 & -0.003 & -0.009 & -0.004 & -0.006 \\
\hline \multirow[t]{2}{*}{ Cash } & $0.218^{* * *}$ & $0.224 * * *$ & $0.204 * * *$ & $0.215 * * *$ & $0.205^{* * *}$ & $0.226^{* * *}$ & $0.197 * * *$ & $0.180 * * *$ \\
\hline & -0.016 & -0.066 & -0.024 & -0.029 & -0.017 & -0.068 & -0.023 & -0.029 \\
\hline \multirow[t]{2}{*}{ Constant } & $-0.384 * * *$ & $-0.594 * * *$ & $-0.507 * * *$ & -0.074 & $-0.438 * * *$ & $-0.556^{* * *}$ & $-0.576^{* * *}$ & -0.167 \\
\hline & -0.048 & -0.145 & -0.07 & -0.104 & -0.048 & -0.142 & -0.07 & -0.102 \\
\hline Yeardummy & Yes & Yes & Yes & Yes & Yes & Yes & Yes & Yes \\
\hline Observations & 7128 & 574 & 4048 & 2506 & 7072 & 569 & 4028 & 2475 \\
\hline Number of Stock Code & 994 & 109 & 628 & 655 & 993 & 108 & 628 & 654 \\
\hline R-squared & 0.16 & 0.18 & 0.16 & 0.16 & 0.16 & 0.16 & 0.16 & 0.16 \\
\hline \multicolumn{9}{|c|}{ Robust standard errors in parentheses } \\
\hline \multicolumn{5}{|c|}{$*$ significant at $10 \% ; * *$ significant at $5 \% ; * * *$ significant at $1 \%$} & & & & \\
\hline
\end{tabular}


Table 7: Results for Equation (1) (Fixed effect model; average leverage over previous three years)

\begin{tabular}{|c|c|c|c|c|c|c|c|c|}
\hline & \multicolumn{4}{|c|}{ Leverage $=($ Total Liabilities $/$ Total assets $) \mathrm{t}-1$} & \multicolumn{4}{|c|}{ Leverage $=($ Bank Liabilities/Total assets $){ }^{t-1}$} \\
\hline & All & CSOEs & LSOEs & NONSOEs & All & CSOEs & LSOEs & NONSOEs \\
\hline & 1 & 2 & 3 & 4 & 5 & 6 & 7 & 8 \\
\hline \multirow[t]{2}{*}{ Leverage } & $-0.093 * * *$ & $-0.370^{* * *}$ & $-0.130 * * *$ & $-0.070 * * *$ & $-0.175^{* * *}$ & $-0.167^{* *}$ & $-0.239 * * *$ & $-0.153^{* * *}$ \\
\hline & -0.019 & -0.096 & -0.035 & -0.024 & -0.017 & -0.07 & -0.024 & -0.03 \\
\hline \multirow[t]{2}{*}{ Tobin's Qt-1 } & $0.009 * * *$ & 0.002 & $0.008 * * *$ & $0.012 * * *$ & $0.009 * * *$ & 0.004 & $0.008 * * *$ & $0.009 * * *$ \\
\hline & -0.002 & -0.004 & -0.003 & -0.003 & -0.001 & -0.004 & -0.002 & -0.003 \\
\hline \multirow[t]{2}{*}{ Size } & $0.036^{* * *}$ & $0.038 * * *$ & $0.041^{* * *}$ & $0.024 * *$ & $0.036^{* * *}$ & $0.036^{* * *}$ & $0.044 * * *$ & $0.024 * * *$ \\
\hline & -0.004 & -0.01 & -0.006 & -0.009 & -0.004 & -0.009 & -0.005 & -0.008 \\
\hline \multirow[t]{2}{*}{ Cash } & $0.214^{* * *}$ & $0.270 * * *$ & $0.193 * * *$ & $0.197 * * *$ & $0.203 * * *$ & $0.241 * * *$ & $0.190 * * *$ & $0.187^{* * *}$ \\
\hline & -0.019 & -0.08 & -0.028 & -0.034 & -0.017 & -0.077 & -0.025 & -0.031 \\
\hline \multirow[t]{2}{*}{ Constant } & $-0.471 * * *$ & $-0.398^{* *}$ & $-0.548 * * *$ & $-0.291^{*}$ & $-0.463^{* * *}$ & $-0.483^{* * *}$ & $-0.603 * * *$ & $-0.267^{* *}$ \\
\hline & -0.066 & -0.166 & -0.096 & -0.153 & -0.058 & -0.154 & -0.084 & -0.134 \\
\hline Yeardummy & Yes & Yes & Yes & Yes & Yes & Yes & Yes & Yes \\
\hline Observations & 4401 & 382 & 2415 & 1604 & 5214 & 447 & 2921 & 1846 \\
\hline Number of Stock Code & 799 & 93 & 518 & 492 & 843 & 101 & 553 & 533 \\
\hline R-squared & 0.12 & 0.25 & 0.12 & 0.1 & 0.14 & 0.17 & 0.15 & 0.13 \\
\hline \multicolumn{9}{|c|}{\begin{tabular}{|l|l|} 
Robust standard errors in parentheses & \\
\end{tabular}} \\
\hline \multicolumn{5}{|c|}{$*$ significant at $10 \% ; * *$ significant at $5 \% ; * * *$ significant at $1 \%$} & & & & \\
\hline
\end{tabular}


Table 8: Results for Equation (2) (Fixed effect model; average leverage over previous three years)

\begin{tabular}{|c|c|c|c|c|c|c|c|c|}
\hline & \multicolumn{4}{|c|}{ Leverage $=($ Total Liabilities $/$ Total assets $) \mathrm{t}-1$} & \multicolumn{4}{|c|}{ Leverage $=($ Bank Liabilities $/$ Total assets $) \mathrm{t}-1$} \\
\hline & All & CSOEs & LSOEs & NONSOEs & All & CSOEs & LSOEs & NONSOES \\
\hline & 1 & 2 & 3 & 4 & 5 & 6 & 7 & 8 \\
\hline \multirow[t]{2}{*}{ Leverage } & $-0.087^{* * * *}$ & $-0.367 * * *$ & $-0.120 * * *$ & $-0.070 * * *$ & $-0.151^{* * *}$ & $-0.161 * *$ & $-0.213 * * *$ & $-0.135^{* * *}$ \\
\hline & -0.018 & -0.096 & -0.033 & -0.024 & -0.017 & -0.069 & -0.025 & -0.03 \\
\hline \multirow[t]{2}{*}{ LQ $\times$ Leverage } & $-0.048^{* * *}$ & -0.006 & $-0.045^{* * *}$ & $-0.043 * * *$ & $-0.067 * * *$ & -0.013 & $-0.056^{* * *}$ & $-0.077 * * *$ \\
\hline & -0.007 & -0.022 & -0.01 & -0.013 & -0.01 & -0.034 & -0.014 & -0.018 \\
\hline \multirow[t]{2}{*}{ Tobin's $\mathrm{Q}_{\mathrm{t}-1}$} & $0.009 * * *$ & 0.002 & $0.008 * * *$ & $0.012 * * *$ & $0.008^{* * *}$ & 0.004 & $0.008 * * *$ & $0.009 * * *$ \\
\hline & -0.002 & -0.004 & -0.003 & -0.003 & -0.001 & -0.004 & -0.002 & -0.003 \\
\hline \multirow[t]{2}{*}{ Size } & $0.039 * * *$ & $0.039 * * *$ & $0.043 * * *$ & $0.027 * * *$ & $0.039 * * *$ & $0.037 * * *$ & $0.046^{* * *}$ & $0.027 * * *$ \\
\hline & -0.004 & -0.01 & -0.006 & -0.009 & -0.004 & -0.009 & -0.005 & -0.008 \\
\hline \multirow[t]{2}{*}{ Cash } & $0.201 * * *$ & $0.268 * * *$ & $0.176^{* * *}$ & $0.192 * * *$ & $0.191 * * *$ & $0.239 * * *$ & $0.177^{* * *}$ & $0.181 * * *$ \\
\hline & -0.019 & -0.082 & -0.027 & -0.034 & -0.017 & -0.079 & -0.025 & -0.03 \\
\hline \multirow[t]{2}{*}{ Constant } & $-0.511 * * *$ & $-0.404^{* *}$ & $-0.583 * * *$ & $-0.324 * *$ & $-0.502 * * *$ & $-0.492 * * *$ & $-0.628 * * *$ & $-0.310^{* *}$ \\
\hline & -0.066 & -0.166 & -0.096 & -0.151 & -0.058 & -0.154 & -0.084 & -0.133 \\
\hline Yeardummy & Yes & Yes & Yes & Yes & Yes & Yes & Yes & Yes \\
\hline Observations & 4401 & 382 & 2415 & 1604 & 5214 & 447 & 2921 & 1846 \\
\hline Number of Stock Code & 799 & 93 & 518 & 492 & 843 & 101 & 553 & 533 \\
\hline R-squared & 0.13 & 0.25 & 0.13 & 0.11 & 0.15 & 0.17 & 0.16 & 0.14 \\
\hline \multicolumn{9}{|c|}{ Robust standard errors in parentheses } \\
\hline \multicolumn{5}{|c|}{$*$ significant at $10 \% ; * *$ significant at $5 \% ; * * *$ significant at $1 \%$} & & & & \\
\hline
\end{tabular}


Table 9 Results for Equation (1) (Instrument variable method; leverage for the prior accounting year)

\begin{tabular}{|c|c|c|c|c|c|c|c|c|}
\hline & \multicolumn{4}{|c|}{ Leverage $=($ Total Liabilities $/$ Total assets $) \mathrm{t}-1$} & \multicolumn{4}{|c|}{ Leverage $=($ Bank Liabilities $/$ Total assets $) \mathrm{t-1}$} \\
\hline & All & CSOEs & LSOEs & NONSOES & All & CSOEs & LSOEs & NONSOEs \\
\hline & 1 & 2 & 3 & 4 & 5 & 6 & 7 & 8 \\
\hline \multirow[t]{2}{*}{ Leverage } & $-0.123^{* * *}$ & 0.108 & $-0.143 * * *$ & $-0.105^{* * *}$ & $-0.513 * * *$ & $-0.402 * * *$ & $-0.534 * * *$ & $-0.462 * * *$ \\
\hline & -0.021 & -0.072 & -0.031 & -0.035 & -0.033 & -0.129 & -0.047 & -0.056 \\
\hline \multirow[t]{2}{*}{ Tobin's $Q^{t-1}$} & $0.011 * * *$ & $0.006^{*}$ & $0.012 * * *$ & $0.010 * * *$ & $0.007 * * *$ & 0.002 & $0.008 * * *$ & $0.006 * *$ \\
\hline & -0.001 & -0.004 & -0.002 & -0.003 & -0.001 & -0.004 & -0.002 & -0.003 \\
\hline \multirow[t]{2}{*}{ Size } & $0.027 * * *$ & $0.033 * * *$ & $0.032 * * *$ & $0.014 *$ & $0.045^{* * *}$ & $0.043 * * *$ & $0.051^{* * *}$ & $0.028 * * *$ \\
\hline & -0.003 & -0.01 & -0.005 & -0.008 & -0.003 & -0.01 & -0.005 & -0.007 \\
\hline \multirow[t]{2}{*}{ Cash } & $0.215^{* * *}$ & $0.219 * * *$ & $0.211^{* * *}$ & $0.182^{* * *}$ & $0.150 * * *$ & $0.170 * *$ & $0.153^{* * *}$ & $0.135^{* * *}$ \\
\hline & -0.017 & -0.07 & -0.025 & -0.032 & -0.017 & -0.069 & -0.024 & -0.031 \\
\hline \multirow[t]{2}{*}{ Constant } & $-0.325^{* * *}$ & $-0.491 * * *$ & $-0.391 * * *$ & -0.107 & $-0.542 * * *$ & $-0.506^{* * *}$ & $-0.628 * * *$ & $-0.264 * *$ \\
\hline & -0.059 & -0.162 & -0.084 & -0.131 & -0.052 & -0.152 & -0.077 & -0.114 \\
\hline Yeardummy & Yes & Yes & Yes & Yes & Yes & Yes & Yes & Yes \\
\hline Observations & 6093 & 513 & 3458 & 2122 & 6093 & 513 & 3458 & 2122 \\
\hline Number of Stock Code & 924 & 105 & 599 & 591 & 924 & 105 & 599 & 591 \\
\hline R-squared & 0.13 & 0.12 & 0.13 & 0.12 & 0.17 & 0.14 & 0.17 & 0.16 \\
\hline \multicolumn{9}{|c|}{\begin{tabular}{|l|l|} 
Robust standard errors in parentheses & \\
\end{tabular}} \\
\hline \multicolumn{5}{|c|}{$*$ significant at $10 \% ; * *$ significant at $5 \% ; * * *$ significant at $1 \%$} & & & & \\
\hline
\end{tabular}


Table 10 Results for Equation (2) (Instrument variable method; leverage for the prior accounting year))

\begin{tabular}{|c|c|c|c|c|c|c|c|c|}
\hline & \multicolumn{4}{|c|}{ Leverage $=($ Total Liabilities $/$ Total assets $) \mathrm{t}-1$} & \multicolumn{4}{|c|}{ Leverage $=($ Bank Liabilities $/$ Total assets $) \mathrm{t}-1$} \\
\hline & All & CSOEs & LSOEs & NONSOEs & All & CSOEs & LSOEs & NONSOEs \\
\hline & 1 & 2 & 3 & 4 & 5 & 6 & 7 & 8 \\
\hline \multirow[t]{2}{*}{ Leverage } & $-0.113^{* * *}$ & 0.104 & $-0.131 * * *$ & $-0.097 * * *$ & $-0.490 * * *$ & $-0.428 * * *$ & $-0.512 * * *$ & $-0.434 * * *$ \\
\hline & -0.021 & -0.072 & -0.031 & -0.035 & -0.034 & -0.129 & -0.047 & -0.057 \\
\hline \multirow[t]{2}{*}{ LQ $\times$ Leverage } & $-0.032^{* * *}$ & 0.006 & $-0.030 * * *$ & $-0.035^{* * *}$ & $-0.041 * * *$ & 0.036 & $-0.037 * * *$ & $-0.057^{* *}$ \\
\hline & -0.006 & -0.018 & -0.008 & -0.011 & -0.011 & -0.033 & -0.014 & -0.023 \\
\hline \multirow[t]{2}{*}{ Tobin's $\mathrm{Q}^{\mathrm{t}-1}$} & $0.011^{* * *}$ & $0.006^{*}$ & $0.012 * * *$ & $0.010 * * *$ & $0.007^{* * *}$ & 0.002 & $0.009 * * *$ & $0.006^{* *}$ \\
\hline & -0.001 & -0.004 & -0.002 & -0.003 & -0.001 & -0.004 & -0.002 & -0.003 \\
\hline \multirow[t]{2}{*}{ Size } & $0.030 * * *$ & $0.033 * * *$ & $0.034 * * *$ & $0.017 * *$ & $0.046 * * *$ & $0.042 * * *$ & $0.052 * * *$ & $0.030 * * *$ \\
\hline & -0.003 & -0.01 & -0.005 & -0.008 & -0.003 & -0.01 & -0.005 & -0.007 \\
\hline \multirow[t]{2}{*}{ Cash } & $0.203 * * *$ & $0.222^{* * *}$ & $0.195^{* * *}$ & $0.178 * * *$ & $0.144 * * *$ & $0.179 * *$ & $0.144 * * *$ & $0.132 * * *$ \\
\hline & -0.017 & -0.072 & -0.025 & -0.032 & -0.017 & -0.072 & -0.024 & -0.031 \\
\hline \multirow[t]{2}{*}{ Constant } & $-0.357 * * *$ & $-0.484 * * *$ & $-0.417 * * *$ & -0.146 & $-0.563 * * *$ & $-0.482 * * *$ & $-0.644 * * *$ & $-0.294 * *$ \\
\hline & -0.059 & -0.162 & -0.085 & -0.131 & -0.053 & -0.153 & -0.077 & -0.115 \\
\hline Yeardummy & Yes & Yes & Yes & Yes & Yes & Yes & Yes & Yes \\
\hline Observations & 6093 & 513 & 3458 & 2122 & 6093 & 513 & 3458 & 2122 \\
\hline Number of Stock Code & 924 & 105 & 599 & 591 & 924 & 105 & 599 & 591 \\
\hline R-squared & 0.13 & 0.12 & 0.14 & 0.13 & 0.17 & 0.14 & 0.18 & 0.16 \\
\hline \multicolumn{9}{|c|}{\begin{tabular}{|l|l|} 
Robust standard errors in parentheses & \\
\end{tabular}} \\
\hline \multicolumn{5}{|c|}{$*$ significant at $10 \% ; * *$ significant at $5 \% ; * * *$ significant at $1 \%$} & & & & \\
\hline
\end{tabular}

